\title{
Developing and Assessing Investment Options for Economic, Energy, and Climate Security Gains in the United States
}

\author{
Pat Delaquil1, Gary Goldstein', Hal Nelson², Thomas Peterson ${ }^{3,4}$, Stephen Roe ${ }^{3}$, \\ Adam Rose $^{5}$, Dan Wei ${ }^{5}$, Jeffery Wennberg ${ }^{3}$ \\ ${ }^{1}$ Decision Ware Group, Annapolis, USA \\ ${ }^{2}$ Claremont Graduate University, Claremont, USA \\ ${ }^{3}$ The Center for Climate Strategies, Washington DC, USA \\ ${ }^{4}$ Johns Hopkins University, Baltimore, USA \\ ${ }^{5}$ University of Southern California, Los Angeles, USA \\ Email: pdelaquil@comcast.net
}

Received 19 February 2014; revised 18 March 2014; accepted 25 March 2014

Copyright (C) 2014 by authors and Scientific Research Publishing Inc.

This work is licensed under the Creative Commons Attribution International License (CC BY).

http://creativecommons.org/licenses/by/4.0/

(c) (i) Open Access

\section{Abstract}

Recent US data indicate a clear and progressive decoupling of carbon emissions and energy intensity from economic growth. This is primarily a consequence of state and national environmental and energy policy actions, and secondarily a result of shifts in economic structure and increases in natural gas supplies. To assess future opportunities of proactive approaches to policy and investment, we analyze 20 sector-based actions at the national and subnational levels in the US that can narrow remaining national carbon emissions gaps by 2020 and beyond, while improving economic and energy efficiency in every sector. These actions are found to provide favorable returns on investment for job creation, energy and cost savings, and multiple measures of energy security. Selection and design of these new actions are based on evaluation of hundreds of policy options derived from facilitated, stakeholder and consensus-based development of comprehensive climate action planning in 20 states. They represent top issues of focus for policymakers, and serve as key drivers for new investment, collaboration, and governance approaches that are needed to integrate economic, energy, and environmental security in the US. This same general approach to planning and analysis is of value to other nations seeking similar benefits. Techniques for comprehensive, multi-objective, fully integrated, and collaborative systems of planning and analysis are important as a means for comprehensive security solutions. This also requires leadership at all levels of government, and a broadened view of national security. 


\section{Keywords}

\section{Greenhouse Gas Mitigation, Macroeconomic Impacts, Energy System Optimization, Energy Security, Policy Design, Integrated Security Metrics System, MARKAL/TIMES}

\section{Introduction}

Research and practice on greenhouse gas (GHG) mitigation policy have identified hundreds of options with potentially positive impacts on economic, energy, and environmental security. Past research and policy focused primarily on GHG emissions reductions, direct (cost effectiveness) economic impacts and indirect (macroeconomic) impacts [1]-[3]. More recently, the focus has progressively addressed a broader and more fully integrated set of policy objectives and impacts, as well as the interface between policies, markets and investments [4]. Policy analysis is increasingly emphasizing the evidence and further opportunities for decoupling of emissions reductions from economic growth and energy security. As a result, the range and design of policy options, their implementation mechanisms, and analytical techniques required for comprehensive analysis have grown and intensified. This paper provides a current assessment for the US.

Today, three principal drivers support this trend: 1) market shift-the recognition of emerging global economies and related energy and industrial shifts, and the potential for specific policy actions to capture and enhance emerging markets in particular locations; 2) energy security - the importance of energy security and sustainability to national economic and environmental policy decisions, including national security; and 3) investment - the reality of significant limitations on public revenues to support policy, and the need and opportunity for mobilization of private investment through new public-private partnerships.

This paper analyzes two important co-objectives of GHG mitigation. First are potential gains to the economy from investment in efficient, low-polluting, and sustainable technologies and practices that are of global benefit. They stem from the fact that many climate mitigation options, such as energy and land-use efficiency, can generate a stimulus through net cost savings that frees up revenue for reinvestment, or that mitigation options reconfigure infrastructure spending approaches to provide higher than average economic growth and employment returns. Second are the national security benefits stemming from reduced dependence on energy in general and fossil fuels in particular, or in diversification of energy supplies toward more indigenous, reliable, and affordable supplies with lower environmental costs. Under certain conditions, these gains can include more secure supplies and decreased energy price volatility, as well as stimulus to the macro economy, while easing the strain on balance of payments.

This paper also provides updated baselines for national carbon emissions and associated energy, economic, and resource activities as a basis for incremental impact analysis of 20 new GHG mitigation and sequestration policy options. Statistical analysis of US Energy Information Administration carbon forecasts and related economic, energy, and policy data shows that a majority of the downward shifts in US carbon baselines can be attributed to state and federal energy policy actions, and that carbon emissions are not necessarily captive to exogenous changes in the economy or energy supplies [5].

To evaluate options for achieving stronger national levels of economic, energy, and environmental security The Center for Climate Strategies (CCS), in cooperation with the Johns Hopkins University Center for Advanced Governmental Studies/Global Security Center, launched The Center for Climate Strategies' Security and Investment Project, Comprehensive Leadership Strategies for the Emerging Energy Economy in 2011 with a select group of policy makers and experts. This initiative builds upon the CCS/Johns Hopkins University 2010 report, Impacts of Comprehensive Climate and Energy Policy Options on the US Economy, which is based on national-scale results of comprehensive state climate action plans developed through stakeholder-based planning and analysis.

To support rapidly expanding interest in this area, and to incorporate new findings and dimensions on policy performance from its 2010 study, CCS has expanded and updated its 2010 framework and analysis. The new focus is to identify and design integrated "triple bottom-line" policy actions at the local, state and national levels designed to simultaneously achieve net positive benefits of economic, energy and environmental security, and to identify investment requirements and potential sources of public and private financing for these actions. Base- 
line updates in the study reflect major shifts in US emissions and energy forecasts, and provide evidence of significant decoupling of carbon emissions, economic growth, and energy security due to proactive policy actions in the energy sector at the state and national levels, indicating that past tradeoff assumptions are not necessarily valid. The identification and assessment of additional stakeholder and expert-derived policy recommendations to expand and accelerate this decoupling provides a comprehensive, evidence-based approach for future actions that can deliver even greater benefits.

\section{Study Methods}

\subsection{Full Spectrum Policy Design and Analysis}

The Security and Investment Project analysis was possible due to the development of the CCS Integrated Security Metrics (ISM) system derived from years of field application across over 20 US states by CCS in the facilitated stakeholder and expert collaboration environment for comprehensive, multi-objective decision-making. CCS has previously used or developed widely-used and peer-reviewed models and modeling approaches that are linked in a comprehensive system to assess the environmental benefits, energy demand, costs or cost savings, fuel prices and macroeconomic impacts of proposed technologies and practices. The ISM system expands the analysis to include additional measures of energy security and of direct investment and financing, and to capture national energy system dynamics. The ISM system assembles all the tools and methods needed to generate security, economic, environmental and investment indicators into a single integrated framework. This same system is under development by CCS in cooperation with the Chinese Academy of Sciences Institute of Policy Management as the China Low Carbon Planning and Analysis Toolkit for provincial and city use. It is also in use by CCS as a part of the Mexico Low Emissions Development Strategies (MLEDS) in the Border States of Mexico. In the US, this system is under consideration as a part of a Best System for Emissions Reduction (BSER) as required for State Implementation Plans under the Clean Air Act, including the Section 111d carbon standards for existing power plants now in rulemaking.

The CCS ISM modeling framework is part of a larger collaboration and analysis process that incorporates CCS facilitated stakeholder and policy maker deliberations into sequentially linked and iterative policy planning and analysis decisions. The policy development and evaluation process is shown schematically in Figure 1 . The CCS ISM system enables policy makers to establish clear, policy relevant baseline activities, and then to identify, design and evaluate new integrated measures that maximize economic, security and environmental benefits across all energy and economic sectors and using all policy instruments. In addition, the system provides policy makers with critical system costs/savings and investment requirements, allowing early consideration of financing measure for implementation. These tools integrate the priorities of economic growth, energy security and environmental benefits (i.e. security and sustainability improvements) into a single policy development process and analytical framework that addresses investment needs.

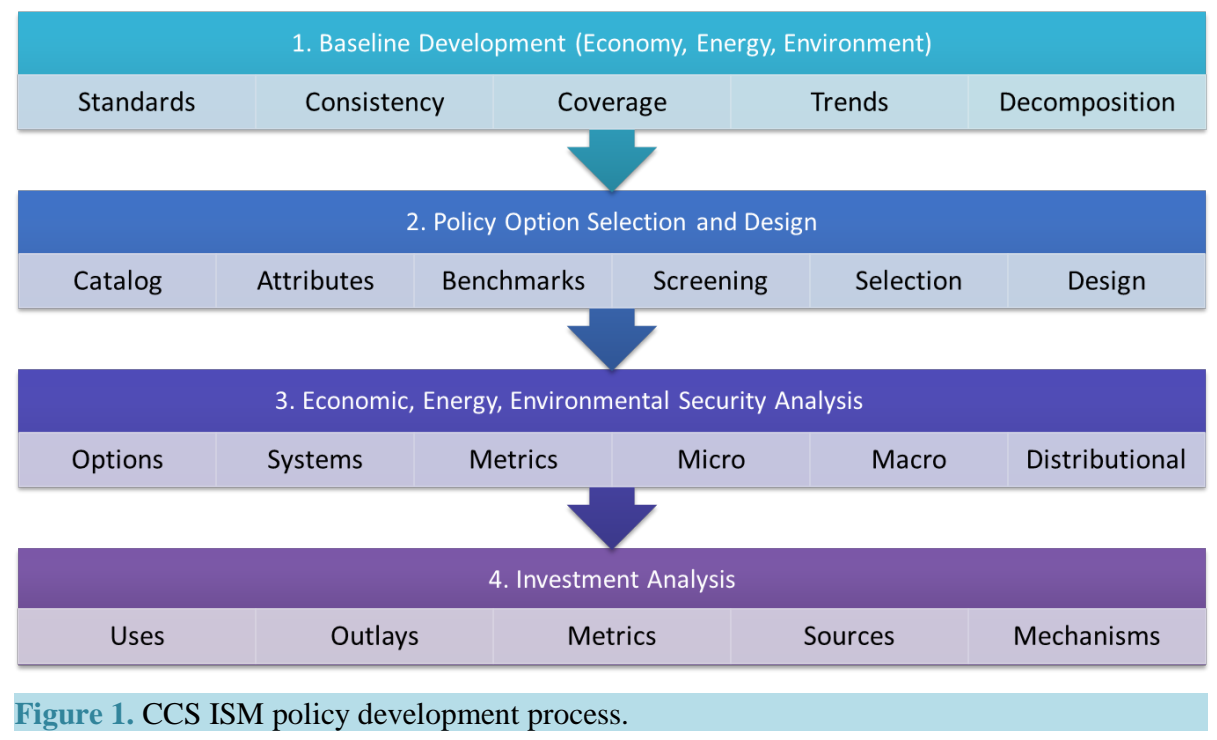


The ISM is broad and comprehensive in nature, combining highly customized, detailed assessment of policy options in all sectors (Agriculture, Forestry, Waste Management, Heat, Power, Residential, Commercial, Industrial, Transportation and Land Use Sectors) with the regional and national energy system strengths of the MARKAL/TIMES least-cost energy system modeling platform. Linkage with the econometrics is embodied in a reduced-form Macroeconomic Screening Tool (CCS, 2012) based on the regression analysis of REMI PI + Macroeconomic Model results of a wide range of GHG mitigation and sequestration policy options. Table 1 provides a brief listing of the key ISM components.

\subsection{Modeling Steps}

Our first step was to identify a set of sector-based policies capable of achieving simultaneous net positive improvements for economic, energy and environmental security going forward. Out of its sample of 20 state climate action plans developed from 2004-2011, CCS identified top measures in each sector with the greatest emissions reduction impact and highest economic and energy security potential. Each of the preliminary set of policies were updated with national-level design and detailed, customized policy specifications (timing, level of effort, coverage of parties, etc.) and implementation instruments (financial incentives, agreements, codes and standards, etc.) needed to achieve three goals: 1) national economic growth as measured by employment and GDP; 2) national energy security as measured by oil imports, indicators of fuel diversity, grid stability, energy intensity, and energy system cost; and 3) national environmental benefits as measured by GHG emissions. The level of government program authorization and implementation was also critical to this optimization process, including assignment of one or more local, state and federal program mechanisms through existing or new authority. This set of major police measures comprise $93 \%$ of the national emissions reduction potential of the several hundred total sector-specific actions included in the state climate plans.

These policy measures were input to the CCS ISM System, including the US National MARKAL model, where they were assessed individually and in integrated clusters to identify their security, investment, and environmental benefits. Some initial sector based policies from the sample pool were dropped at the national level because of poor performance against the three primary screening metrics, and a few were merged to improve their overall performance and or streamline implementation. Measures such as a government policy to build 15 GW of new nuclear power plants by 2030, incentives for converting existing coal power plants to natural gas

\section{Table 1. ISM components.}

\begin{tabular}{|c|c|}
\hline Function & Module \\
\hline Baseline analysis & $\begin{array}{l}\text { Energy sectors: AEO/NEMS (US DOE/EIA); Non-energy sectors: } \\
\text { CCS modified EPA national inventory for agriculture, forestry, waste } \\
\text { management, fossil fuel industries, and industrial process emissions; } \\
\text { CCS forecast for each non-energy sector }\end{array}$ \\
\hline $\begin{array}{l}\text { Microeconomic and direct energy, resource } \\
\text { and environmental impacts }\end{array}$ & $\begin{array}{l}\text { Customized analysis of policy options for each sector (agriculture, } \\
\text { forestry, waste management, heat, power, residential, commercial, } \\
\text { industrial, transportation and land use) using standard principles and } \\
\text { guidelines for impact analysis, and including as needed MARKAL/TIMES } \\
\text { for the energy sector, and CCS expert spreadsheet analysis for specific } \\
\text { policy options in both energy and non-energy sectors }\end{array}$ \\
\hline National energy security and systems impacts & MARKAL/TIMES \\
\hline Investment needs & $\begin{array}{l}\text { MARKAL/TIMES, CCS Macroeconomic Screening Tool, } \\
\text { and REMI Policy Insight Plus }\end{array}$ \\
\hline Investment options & $\begin{array}{l}\text { CCS Macroeconomic Screening Tool and REMI Policy Insight Plus, } \\
\text { CCS financing expertise }\end{array}$ \\
\hline Macroeconomic screening and policy option design & CCS Macroeconomic Screening Tool, CCS sector based expertise \\
\hline Macroeconomic impacts & REMI Policy Insight Plus \\
\hline Sectoral and small business distributional impacts & REMI Policy Insight Plus, CCS small business tool \\
\hline Personal income distribution & REMI Policy Insight Plus; Multi-sector income distribution matrix \\
\hline Multi-attribute screening & Multi Criteria Analysis (MCA) using CCS policy options matrix and benchmarking \\
\hline Health module (air, water quality) & MARKAL/TIMES \\
\hline
\end{tabular}


combined cycle power plants, and a Clean Energy Standard of 60\% by 2030, were dropped because they either reduced job growth, energy system diversity, or had negative or little impact on GDP growth. Other measures, such as redesigned approaches to a national clean energy standard, integrated waste reduction, recycling and landfill gas utilization were combined into an integrated measure. The final set of 20 sector-based policy measures reported in this study is listed in Column 1 of Annex 1 Table.

The analysis was performed using a combination of sector and options specific ISM analysis and a full-sector US National MARKAL model (see below). It includes estimates of the expenditures necessary to implement the policies and bring the needed technologies to market, and the returns from investment in terms of expanded economic, energy and environmental security metrics in the US. This information then served as the basis for our examination of policy and market financing needs and opportunities.

To analyze the microeconomic effects of each sector-based policy action, the US National MARKAL model incorporated ISM results and evaluated all cost requirements and impacts, including new expenditures for plants, equipment, operations, maintenance, financing, etc., imposed by the policy. It then reduced these costs by any savings in fuel, labor, maintenance, and offsetting investments. This analysis provides net direct societal cost, which is important to policy makers who must judge the overall societal benefits of a proposed policy.

Investment flows and outlays were identified as needed to implement the policies. Estimates of these investment flows provide valuable information for policy makers seeking less intrusive means of leveraging public and private sector resources toward the effective implementation of a desired policy. The ties between investments and policy actions are described in more detail elsewhere in this paper.

A Macroeconomic Screening Tool, which is empirically derived from full REMI macroeconomic studies for four US state climate action plans (see below), was used to estimate the macroeconomic impacts, particularly on employment and GDP, as an aide to policy selection and design. The results of the MARKAL analysis of the energy system response to each policy measure were fed to the Macroeconomic Screening Tool to get the preliminary assessment on the jobs and GDP impact of each policy. A snapshot of the framework is shown in Figure 2.

The CCS ISM system also offers significant flexibility for the investigation of scenarios. For energy-related options, the system is built upon a least-cost platform, but it can also solve for environmental, security or alternative economic parameters. As examples, policy makers can test a series of GHG reduction targets, or establish limits on oil imports, or set a minimum reduction in grid summer peak demand, or a target a specific level of new investment, and the system will find the least cost set of policies, technologies and measures that satisfy these constraints. This comprehensive multi-objective capability gives policy makers dramatically enhanced opportunities to understand and fine-tune complex interactive policy scenarios.

\section{CCS Integrated Security Metrics System}

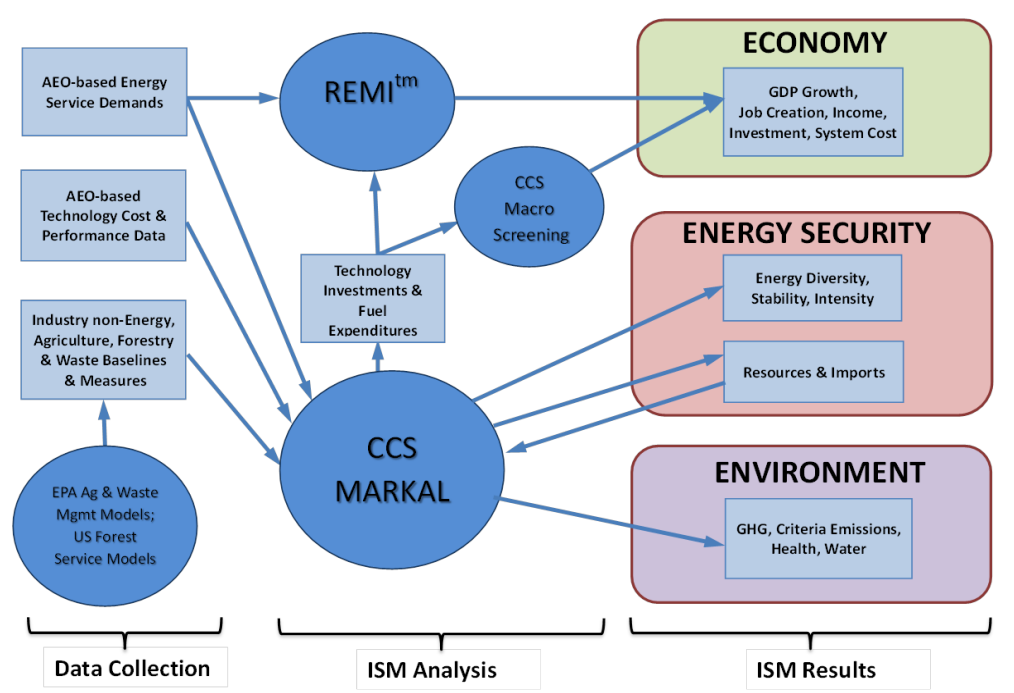

Figure 2. Comprehensive CCS ISM analytical framework. 


\subsection{Energy Sectors}

For each energy sector, customized policy specifications and assumptions derived from the sample pool of policy actions were analyzed with the full-sector US national MARKAL model [6], which is main analytical engine in the ISM system. MARKAL/TIMES is an energy systems modeling platform that is a widely used and proven analytic framework for assessing a wide range of energy, economic and environmental planning and policy issues. The MARKAL/TIMES framework is developed, maintained and continually improved under the auspice of the International Energy Agency_Energy Technology Systems Analysis Programme [7] and [8]. The US National MARKAL model used by CCS:

- Encompasses the entire US energy system from resource extraction through to end-use demands (thus "wellto-wheels"), as represented by a Reference Energy System network

- Employs least-cost optimization

- Identifies the most cost-effective pattern of resource use and technology deployment over time

- Provides a framework for the evaluation of mid-to-long-term policies and programs that can impact the evolution of an energy system

- Quantifies the costs and technology choices that result from adoption of the policies and programs

The starting point US National MARKAL model utilizes US DOE technology cost and performance data and assumptions as provided by the AEO2011 for national policy analysis. The CCS emission baselines also utilize AEO2011 projections, but the AEO and the starting point MARKAL model are limited to $\mathrm{CO}_{2}$ emissions and system costs associated with energy use only. For a complete assessment of GHG emissions, non-energy use $\mathrm{CO}_{2}$ emissions and non- $\mathrm{CO}_{2}$ GHG emissions (methane, nitrous oxide, etc.) were added to the MARKAL model. Emissions sources and sinks in the agriculture, forestry and much of the waste sector are also not included in the AEO and the National MARKAL model. CCS resolved these limitations by incorporating the baseline emissions, policy analysis results and costs from these additional sectors and sources into the starting point US National MARKAL model to create an integrated MARKAL-CCS model.

The results handling aspects MARKAL-CCS were enhanced to provide multiple energy security metrics. These include changes in the demand for imported oil, total fuel mix diversity, electric generation fuel mix diversity, electric grid stability as measured by changes in summer peak demand, and overall national energy intensity per unit of GDP.

Two important sources of emissions were not fully included in baseline or the analysis of potential mitigation options. Upstream emissions from oil and gas extraction and production, such as methane release from wells. Methane emissions from the natural gas transmission and distribution system were included, but mitigation measures were not modeled for this analysis. Non-energy-related industrial process emissions or mitigation measures were also not modeled. Both are key areas of emission growth, as well as the application of technology and best practices for additional study.

\subsection{Non-Energy Sectors}

Non-energy sectors were analyzed with customized spreadsheets and models using specifications and assumptions derived from the sample pool of policy actions. Historic inventory data (1990-2009) were taken from EPA's National GHG Inventory Report [9]. Forecasts for each non-energy sector (Industrial Processes, Agriculture, Forestry, \& Waste Management) were built from a combination of forecasted activity (e.g., US Department of Agriculture livestock operations) and historic trends (e.g., land use change from the USDA Natural Resource Inventory; landfill gas collection trends, US Bureau of Economic Analysis forecasts of personal consumption growth).

Non-energy sector measures selected for analysis under this project were a subset of those commonly selected within US state planning processes that tend to achieve positive micro- and macro-economic impacts, as well as energy and/or GHG reduction benefits. The following measures were addressed:

- Crop Production Practices: Soil Carbon Management

- Crop Production Practices: Nutrient Management

- Livestock Manure-Anaerobic Digestion \& Methane Utilization (Dairy Sector)

- Forest Retention

- Reforestation/Afforestation

- Urban Forestry 
- Municipal Solid Waste (MSW) Source Reduction

- Enhanced MSW Recycling

- MSW Landfill Gas Management

Note that although these measures are directed at sources considered to be in the "non-energy sector", there are energy impacts associated with most of the measures. These include fuel and electricity savings for crop production practices, urban forestry (shading and wind protection of buildings), and MSW source reduction and recycling. Other energy impacts include renewable energy generation from methane utilization (livestock and landfill gas) and increased biomass utilization under the forestry options. Full energy and non-energy related GHG reductions were captured in the analysis of each measure (e.g., energy use reductions, renewable energy generation, terrestrial carbon enhancements, and reduced methane and nitrous oxide emissions).

\subsection{Macroeconomic Analysis}

While the MARKAL-CCS model is capable of generating technology and policy-specific costs and savings for each measure, macroeconomic impacts, beyond the response of energy service demands to changes in energy price, are not available through this platform. To provide the critical GDP and employment results CCS has developed a Macroeconomic Screening Tool, which is derived from applications of the full Regional Economic Models Inc., (REMI) Policy Insight Plus (PI+) Model for four US state climate action plans (see, e.g., [10]-[13]). This tool provides fast and inexpensive predictions of impacts on employment and GDP for both energy and non-energy sector policies as an aide to policy selection and design. It is described in greater detail in the Macroeconomic Screening Tool document [14].

The screening tool provides reliable guidance on the direction and relative magnitude of changes in employment and GDP, but it is only a placeholder for a full REMI macroeconomic impact analysis, which provides not only more accurate but much more detailed results. The CCS ISM links the MARKAL-CSS outputs to the reduced-form economic platform, providing a comprehensive set of analyses through a single integrated system.

The CCS Macroeconomic Screening Tool is based on reduced-form multivariate statistical models that examine the relationship between the macroeconomic impacts (GDP and employment) of the GHG mitigation options yielded by the REMI analyses and various microeconomic costs, structural linkages and other characteristics of these options. The two main explanatory variables in the regression models are the direct net cost and the investment requirements of the mitigation options. The models also include eight binary variables to help explain the option-specific characteristics, such as sectors, capital investment on construction vs. equipment, government subsidy, etc.

The models yield robust summary measures, as indicated by the multiple correlation coefficient (R-squared) values. The regression model for the GDP impacts has an R-squared of 0.71 , while the model for the employment impacts has an R-squared of 0.82 . These indicate that the models explain about 71 percent and 82 percent of the variance in the GDP and employment impacts across our pooled sample, respectively. The models also indicate that explanatory variables such as direct net costs and investment requirements have significant impacts on the overall GDP and employment impacts of the mitigation option.

This Macroeconomic Screening Tool does not include analysis of the interactive and aggregate effects of individual policy actions at this stage. Interactive analysis would likely identify stronger aggregate economic benefits for actions that cross sectors. For instance, by combining energy savings and cost reductions for energy efficiency measures with positive cost options for renewable energy, the level of aggressiveness of both actions could be increased without reducing overall macroeconomic benefit. As a result, the findings of this analysis should not be taken as an upper limit to actions with positive net macroeconomic benefit, and instead should be viewed as a lower limit at this time. This is an important area for future study.

\section{Results}

The analysis shows that the 20 final measures, when applied selectively to all 50 states (based on state and sector characteristics), achieve the three primary security and sustainability goals and could provide the aggregated benefits summarized below:

1) Increase US employment by 1.33 million net new full-time jobs by 2020 ;

2) Increase GDP by $\$ 96$ billion in 2020 and cumulatively by $\$ 1.06$ trillion (in net present value) between now and 2030; 
3) Reduce US oil imports by 135 million barrels in 2020 and cumulatively by almost 5.1 billion barrels between now and 2030;

4) Increase US fuel diversity, reduce summer peak demand for electricity, generate direct societal cost savings and reduce US energy intensity (energy use per unit GDP);

5) Reduce GHG emissions by about 466 million metric tons of $\mathrm{CO}_{2}$ equivalent in 2020, and cumulatively by about 13.5 billion metric tons of $\mathrm{CO}_{2}$ equivalent between now and 2030 .

Figure 3 shows the direct investment flow requirements and employment benefits of the policies by economic sector. Also shown is the direct investment cost per full time job (by employee-year) created between now and 2030. Integrated economic, energy, environmental security investment creates jobs at favorable investment rates in comparison to conventional economic development alternatives. The aggregate result over all sectors would create, on average, one job per $\$ 24,000$ invested. The Residential, Commercial and Industrial (RCI) sector policies are the most cost-effective in this regard, followed by Agriculture, Forestry and Waste (AFW) sector policies. The Transport and Land-Use (TLU) policies are more expensive due to infrastructure costs required by some of the measures, and Electricity and Heat Supply (EHS) investment requirements per job are higher than the average because of the high capital investments required by the renewable energy (biomass, geothermal, hydropower, solar and wind) power plants.

Figure 4 shows return on direct investment in terms of energy savings achieved by the 20 measures. The aggregated impact of all the measures shows a significant savings to the energy system total cost due to the fuel savings achieved in the RCI and TLU sectors by energy efficiency. The EHS sector shows a relatively small incremental investment need compared to the RCI and TLU sectors, and shows an increase in energy system costs due to the current higher cost of clean energy technologies. Economic results for each individual measure are available in Annex 1 to this paper.

Figure 5 shows the six energy security metrics used in the analysis. While one or two measures in a few sectors show slightly negative results, the aggregate metrics are significantly positive. The RCI sector shows the most significant improvements, especially for fuel and electricity diversity, while the TLU sector shows significant gains due to reduced oil imports. The energy security metrics for each individual measures are presented in Annex 2.

The emission reductions from each individual measures are presented in Annex 2. At the aggregate sector level, measures from the RCI sector achieve the greatest reductions at 9.1 billion metric tons of CO2e. Next are the AFW, EHS, and TLU sectors are estimated to result in GHG emission reductions of 4.1, 3.0, and 2.0 billion metric tons of CO2e, respectively.

Figure 6 shows the impact of the 20 new measures on attainment of national GHG goals by 2020. Note that

\section{Security Investment and Jobs 2010 - 2030}

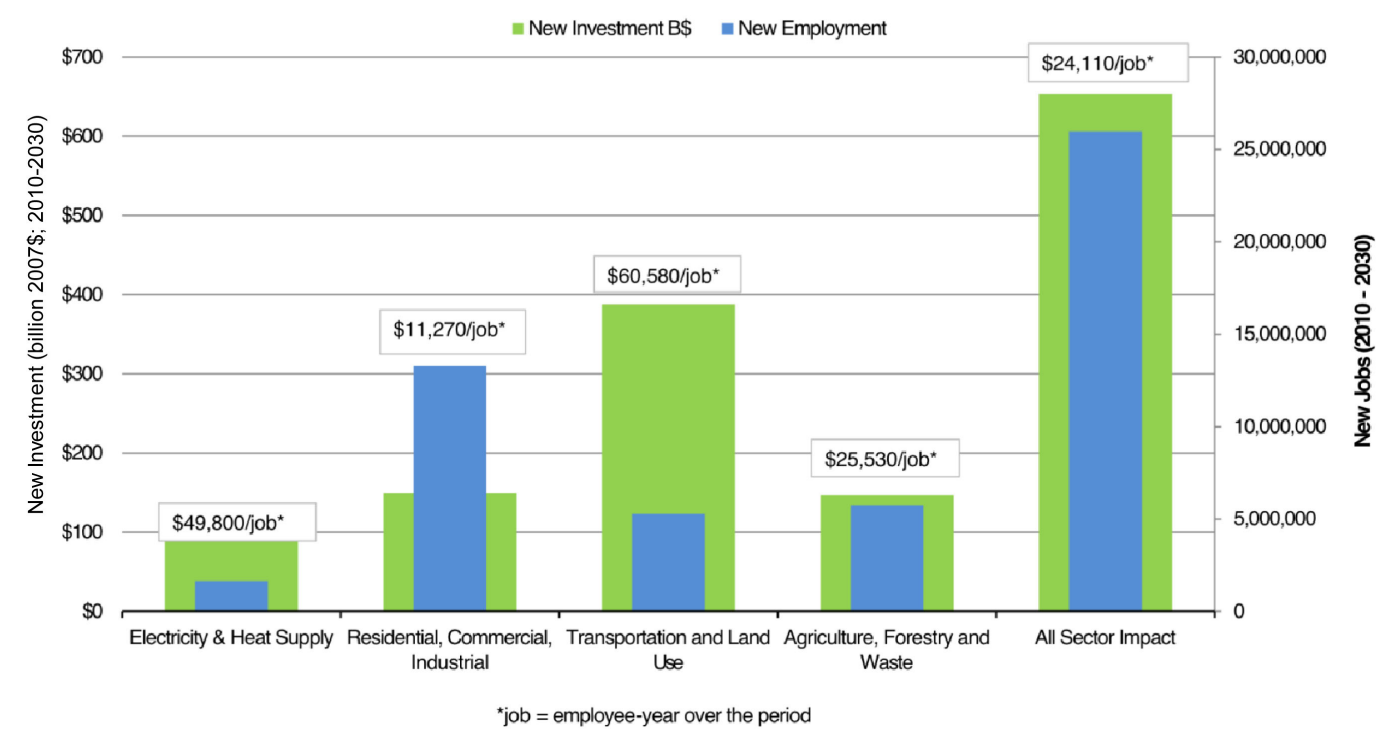

Figure 3. Return on investment for job creation. 
Direct Cost (Savings) \& Investment Requirements - AШSector

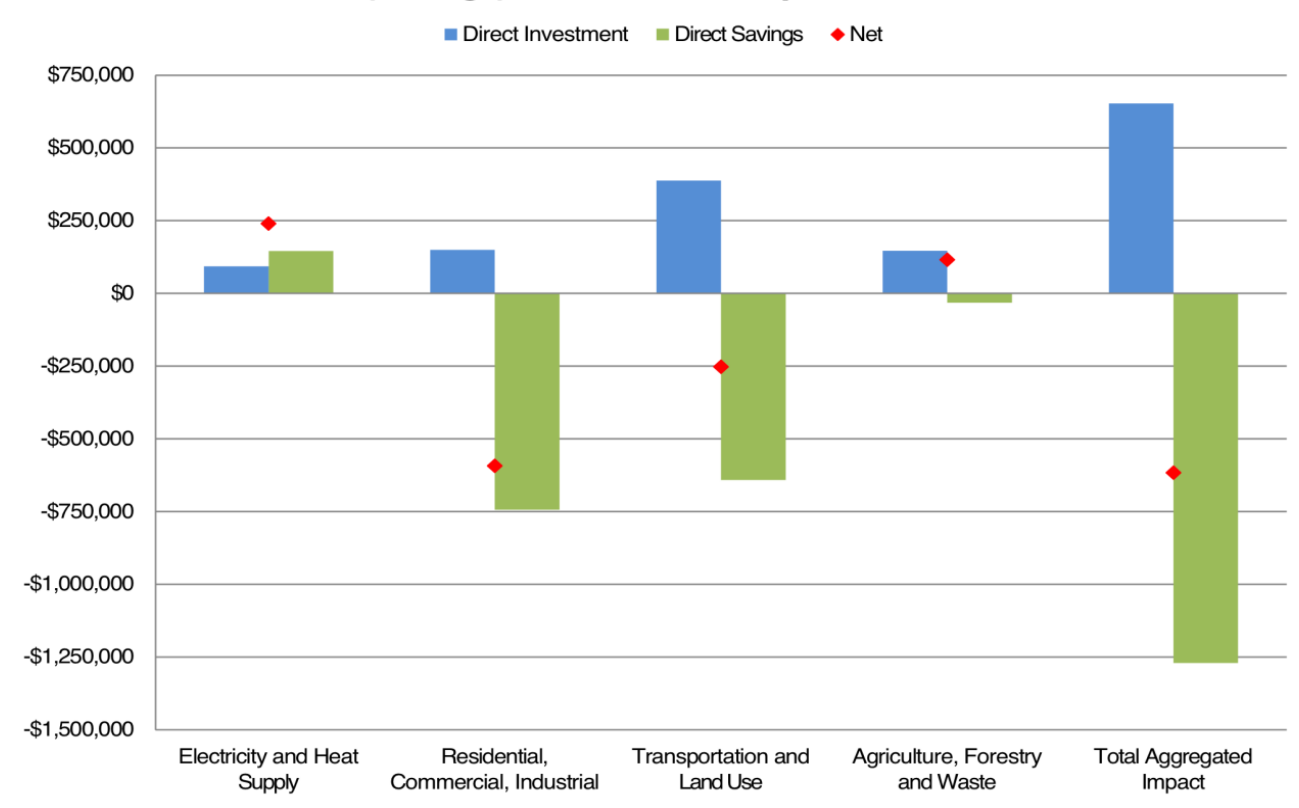

Figure 4. Return on investment for energy savings.

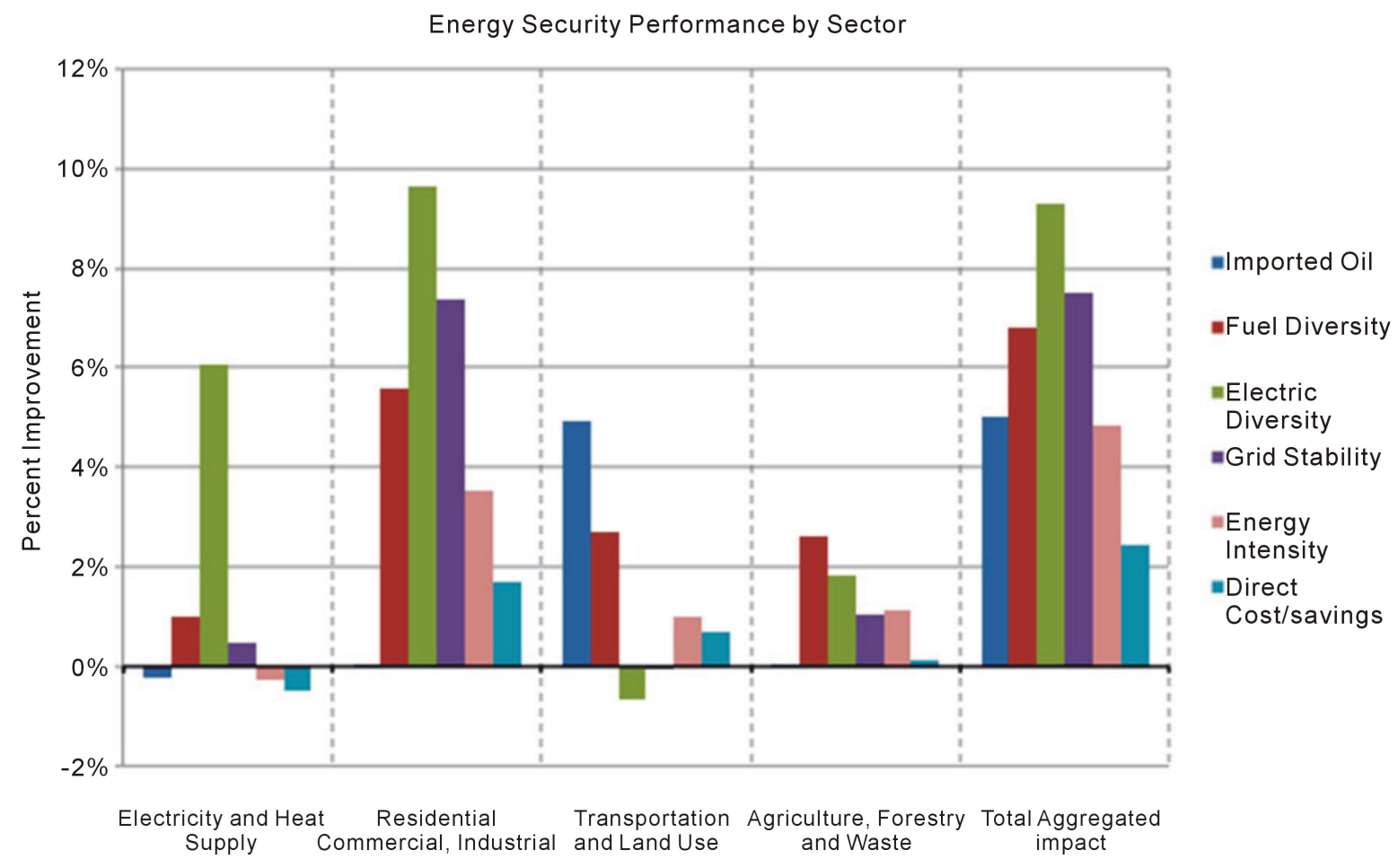

Figure 5. Energy security gains.

the 20 measures do not fully include actions to reduce emissions associated with: 1) Industrial non-energy, which includes cement manufacturing and other industrial processes that release $\mathrm{CO}_{2}$, methane and other industrial gases that are GHG pollutants, and 2) Fossil fuel production, which includes coal mine methane emissions and emissions from oil and natural gas production, processing, transport, storage and distribution. Given the sig- 


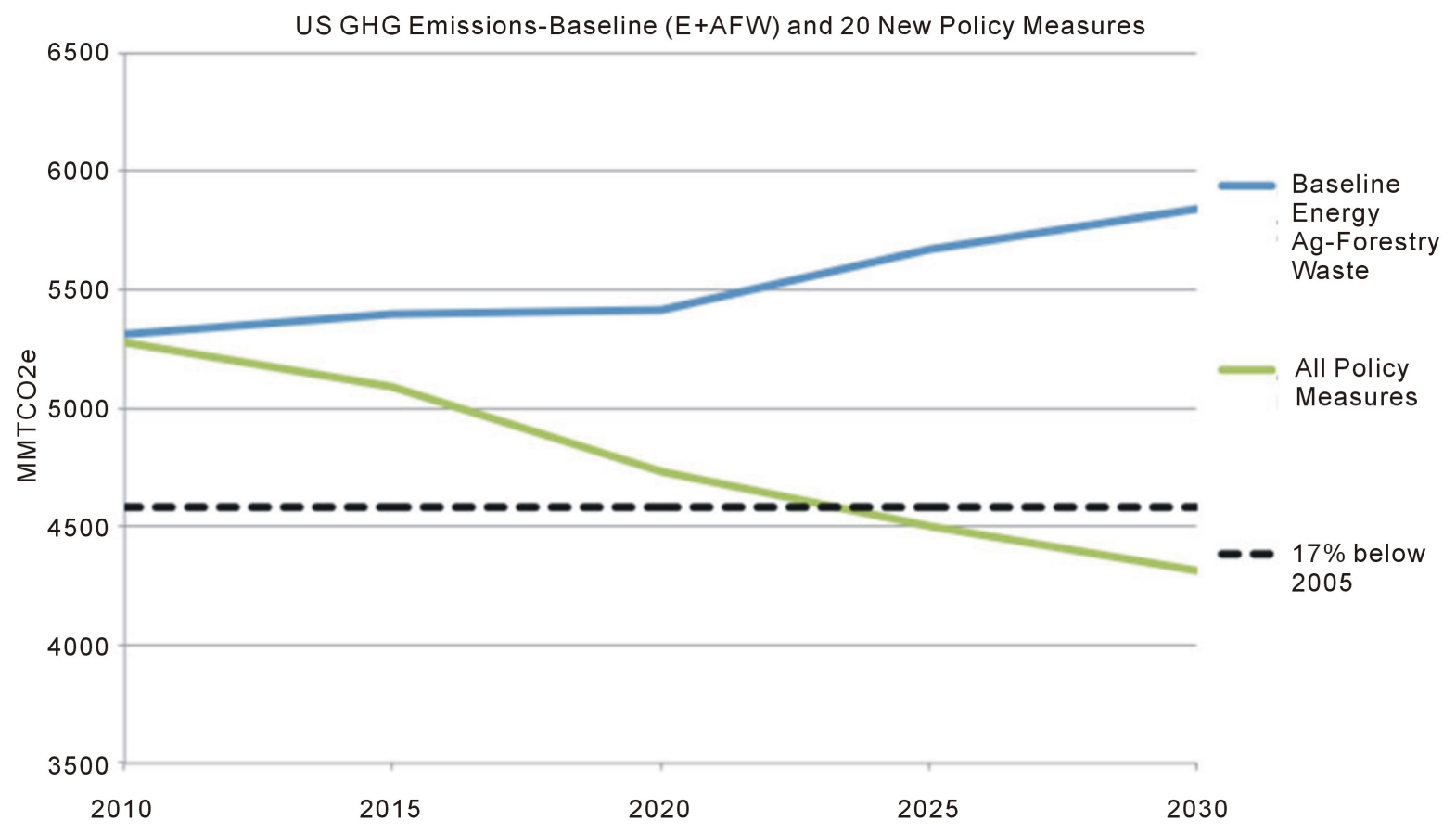

Figure 6. Impacts of new measures on national GHG goals.

nificant increase in oil and gas exploration and distribution in the US since these state climate action plans were developed, reductions from this sector could be large.

\section{Conclusions}

Four major findings result from this work.

First, the right combination of targeted actions in each sector at the national and subnational levels can expand national economic, energy, and environmental security in a mutually reinforcing manner. Tradeoffs are not inevitable or insurmountable. To the contrary, holistic approaches create important new synergies. Analysis of 20 new sector-based actions indicate that the changes within sectors needed to reach national GHG goals by 2020 and simultaneously advance economic and energy security are not large compared to the total economy. However, the gaps and related implementation barriers are significant and require a dedicated effort by policy makers and stakeholders.

Second, these actions constitute an attractive investment opportunity, and the policy mechanisms for each stimulate beneficial gains in the economy. The view that outlays required for new policy are costs should be replaced by the view that these are value added investments. New investments depend on and are driven by policy choices and tools. US has a large population of investors who control an enormous pool of capital that could be used to implement many of the 20 proposed policy measures in this study. Collaborative planning and analysis that include both policy makers and investors could target barrier removal mechanisms.

Third, bottom up policy planning can improve governance. Comprehensive approaches provide a roadmap of the specific roles of subnational and national programs, and can guide their integration. The interface between subnational and national implementation of these actions is particularly important. Roughly two-thirds of the 20 sector-based measures identified in this study involve primary or shared jurisdiction by states and localities with federal programs.

Fourth, the findings of this study are consistent with many other economic and energy impact studies, which find that properly selected and designed policies can generate net positive effects on the economy, energy security and sustainability, and pollution reduction [15]. For instance, CCS has conducted a series of analyses of state level climate action plans using the REMI PI+ Model that illustrate positive results for the majority of options in plans that show how climate actions can induce economic development. Other studies document the growth of an emerging clean economy and clean energy market place at the global scale that is among the fastest 
growing market segments worldwide. Indeed, before the global recession, many US states and other nations were enacting policies that reduced emissions concurrent with economic growth, and later as means to achieve economic stimulus during the recession. In addition, decoupling strategies are now becoming more common as a goal of national and sub national policy. For instance, under its most recent Five Year Economic Plan, China's national government has assigned dual goals for each of its provinces for economic growth and emissions reduction in an effort to foster both. Development banks are pursuing decoupling strategies to accelerate sustainable economic and energy development.

\section{References}

[1] Weyant, J. (1999) Special Issue on the Costs of the Kyoto Protocol: A Multi-Model Evaluation. Energy Journal, 21.

[2] Barker, T., Kohler, J. and Villena, M. (2002) Costs of Greenhouse Gas Abatement: Meta-Analysis of Post-SRES Mitigation Scenarios. Environmental Economics and Policy Studies, 5, 135-166.

[3] Rose, A. and Dormady, N. (2011) A Meta-Analysis of the Economic Impacts of Climate Change Policy in the United States. The Energy Journal, 32, 143-165. http://dx.doi.org/10.5547/ISSN0195-6574-EJ-Vol32-No2-6

[4] Wennberg, J., Rose, A. and Wei, D. (2010) Impacts of Comprehensive Climate and Energy Policy Options on the US Economy. Johns Hopkins University, Center for Climate Strategies, Baltimore.

[5] Nelson, H., von Hippel, D., Peterson, T. and Garagulagian, R. (2014) The Great Recession or Progressive Energy Policies? Explaining the Decline in US Greenhouse Gas Emissions Forecasts. Claremont Graduate University Working Paper, Claremont.

[6] IRG (2006) Final Report on Support, Update and Improvement of USEPA MGA-MARKAL Model Database. International Resources Group, Washington DC.

[7] ETSAP (2012) http://www.iea-etsap.org/web/index.asp

[8] Loulou, R., Goldstein, G. and Noble, K. (2004) Documentation for the MARKAL Family of Models. International Energy Agency Energy Technology Analysis Programme (IEA-ETSAP).

http://www.iea-etsap.org/web/Documentation.asp

[9] EPA (2011) National Greenhouse Gas Emissions Data. http://epa.gov/climatechange/emissions/usinventoryreport.html

[10] Rose, A., Wei, D. and Dormady, N. (2011) Regional Macroeconomic Assessment of the Pennsylvania Climate Action Plan. Regional Science Policy and Practice, 3, 357-379. http://dx.doi.org/10.1111/j.1757-7802.2011.01048.x

[11] Rose, A. and Wei, D. (2012) Macroeconomic Impacts of the Florida Energy and Climate Change Action Plan. Climate Policy, 12, 50-69. http://dx.doi.org/10.1080/14693062.2011.579257

[12] Miller, S., Wei, D. and Rose, A. (2010) The Macroeconomic Impact of the Michigan Climate Action Council Climate Action Plan on the State's Economy. Report to Michigan Department of Environmental Quality. http://www.climatestrategies.us/ewebeditpro/items/O25F22416.pdf

[13] Wei, D. and Rose, A. (2011) The Macroeconomic Impact of the New York Climate Action Plan: A Screening Analysis. Report to New York State Energy Research and Development Authority.

[14] CCS (2012) Macroeconomic Screening Tool. http://www.climatestrategies.us/library/library/view/986

[15] Nelson, H., Rose, A., Wei, D., Peterson, T. and Wennberg, J. (2014) Intergovernmental Climate Change Mitigation Policy: Theory and Outcomes. Journal of Public Policy, Forthcoming. 
Annex 1: Individual Policy Results: Economic Indicators

\begin{tabular}{|c|c|c|c|c|c|c|c|c|}
\hline \multirow[b]{2}{*}{ Sector } & \multirow{2}{*}{$\begin{array}{l}\text { Selected Policy Measures } \\
\text { Policy Description }\end{array}$} & \multicolumn{2}{|c|}{$\begin{array}{l}\text { Net Direct Societal } \\
\text { Cost M2007\$ }\end{array}$} & \multicolumn{2}{|c|}{$\begin{array}{l}\text { New Employment } \\
\text { (Person-Years) }\end{array}$} & \multicolumn{2}{|c|}{$\begin{array}{l}\text { Change in GDP } \\
\text { M2007\$ }\end{array}$} & \multirow{2}{*}{$\begin{array}{c}\text { Change in } \\
\text { Societal } \\
\text { Investment } \\
\text { M2007\$ } \\
2010-2030\end{array}$} \\
\hline & & 2020 & 2010-2030 & 2020 & 2010-2030 & 2020 & 2010-2030 & \\
\hline EHS-1 & $\begin{array}{l}\text { National Renewable Electricity } \\
\text { Standard-20\% by } 2030\end{array}$ & $\$ 6579$ & $\$ 162,323$ & 12,523 & 991,393 & $-\$ 6425$ & $-\$ 165,734$ & $\$ 94,638$ \\
\hline EHS-2 & $\begin{array}{l}\text { Incentives for Combined Heat and } \\
\text { Power }\end{array}$ & $-\$ 2388$ & $-\$ 16,349$ & 40,364 & 652,658 & $\$ 4964$ & $\$ 57,667$ & $\$ 21,500$ \\
\hline EHS-AGG & Electricity and Heat Supply & $\$ 4191$ & $\$ 145,974$ & 52,887 & $1,644,051$ & $-\$ 1461$ & $-\$ 108,067$ & $\$ 87,188$ \\
\hline RCI-1 & $\begin{array}{l}\text { Industrial Process Efficiency and } \\
\text { DSM Measures }\end{array}$ & $-\$ 7489$ & $-\$ 99,918$ & 103,898 & 2,156,391 & $\$ 6926$ & $\$ 88,214$ & $\$ 45,188$ \\
\hline RCI-2 & $\begin{array}{l}\text { DSM Programs for Building } \\
\text { Electricity \& Natural gas Use }\end{array}$ & $-\$ 1335$ & $-\$ 112,010$ & 54,177 & $2,659,139$ & $\$ 4376$ & $\$ 106,641$ & $\$ 6,886$ \\
\hline RCI-3 & Zero Net Energy Buildings & $-\$ 17,161$ & $-\$ 194,131$ & 164,335 & $3,132,090$ & $\$ 10,009$ & $\$ 118,852$ & $-\$ 34,940$ \\
\hline RCI-4 & Appliance Standards & $-\$ 17,566$ & $-\$ 156,890$ & 130,965 & $2,122,703$ & $\$ 7907$ & $\$ 82,653$ & $-\$ 26,054$ \\
\hline RCI-5 & $\begin{array}{l}\text { Advanced Building Codes- } \\
\text { Commercial \& Residential }\end{array}$ & $-\$ 16,336$ & $-\$ 180,425$ & 161,941 & 3,217,089 & $\$ 8664$ & $\$ 106,517$ & $-\$ 1706$ \\
\hline RCI-AGG & Residential, Commercial, Industrial & $-\$ 59,887$ & $-\$ 743,374$ & 615,316 & $13,287,412$ & $\$ 37,882$ & $\$ 502,877$ & $\$ 25,772$ \\
\hline TLU-1 & Rebates for PHEVs and EVs & $-\$ 30,661$ & $-\$ 279,488$ & 103,354 & 831,569 & $\$ 11,016$ & $\$ 90,575$ & $\$ 32,745$ \\
\hline TLU-2 & $\begin{array}{l}\text { National Renewable Fuel Standard } \\
\text {-Post } 2022\end{array}$ & $\$ 153$ & $\$ 45,608$ & 22,034 & 231,610 & $\$ 1902$ & $\$ 11,625$ & $\$ 8977$ \\
\hline TLU-3 & Smart Growth—Land Use—Strong & $-\$ 19,443$ & $-\$ 237,576$ & 73,644 & $1,446,169$ & $\$ 7137$ & $\$ 87,404$ & $-\$ 127,432$ \\
\hline TLU-4 & Public Transit & $\$ 5048$ & $\$ 32,784$ & 32,365 & 658,515 & $\$ 2873$ & $\$ 42,016$ & $\$ 59,858$ \\
\hline TLU-5 & $\begin{array}{l}\text { Anti-Idling Technologies and } \\
\text { Practices-Rapid response }\end{array}$ & $-\$ 2797$ & $-\$ 28,091$ & 34,333 & 666,909 & $\$ 2878$ & $\$ 34,473$ & $\$ 1788$ \\
\hline TLU-6 & Mode Shift from Truck to Rail & $-\$ 22,526$ & $-\$ 291,016$ & 109,526 & $2,079,596$ & $\$ 10,538$ & $\$ 130,728$ & $-\$ 71,034$ \\
\hline TLU-7 & $\begin{array}{l}\text { National CAFE Standard—- } \\
\text { Post } 2025 \text { Targets }\end{array}$ & $\$ 2$ & $\$ 116,470$ & -4184 & $-626,082$ & $\$ 249$ & $-\$ 29,332$ & $\$ 53,619$ \\
\hline TLU-AGG & Transportation and Land Use & $-\$ 70,225$ & $-\$ 641,310$ & 371,071 & $5,288,285$ & $\$ 36,594$ & $\$ 367,488$ & $-\$ 38,338$ \\
\hline AFW-1 & $\begin{array}{l}\text { Crop Production \& Nutrient } \\
\text { Management Practices }\end{array}$ & $\$ 1033$ & $\$ 11,265$ & 20,476 & 350,753 & $\$ 4464$ & $\$ 56,987$ & $\$ 11,279$ \\
\hline AFW-2 & $\begin{array}{l}\text { Agricultural Livestock Manure } \\
\text { Management Practices }\end{array}$ & $\$ 254$ & $\$ 2,941$ & 31,383 & 645,108 & $\$ 3880$ & $\$ 49,913$ & $\$ 1284$ \\
\hline AFW-3 & Forest Retention Practices & $\$ 47$ & $\$ 576$ & 18,903 & 395,316 & $\$ 2036$ & $\$ 26,223$ & $\$ 2617$ \\
\hline AFW-4 & Reforestation Management Practices & $\$ 166$ & $\$ 1768$ & 21,023 & 428,171 & $\$ 2044$ & $\$ 26,271$ & $\$ 1039$ \\
\hline AFW-5 & Urban Forest Management Practices & $\$ 4853$ & $\$ 41,117$ & 124,676 & 2,438,463 & $\$ 2106$ & $\$ 35,082$ & $-\$ 12,922$ \\
\hline AFW-6 & $\begin{array}{l}\text { Integrated Waste Reduction, } \\
\text { Recycling and LGF Utilization }\end{array}$ & $-\$ 7706$ & $-\$ 89,707$ & 69,932 & $1,495,543$ & $\$ 8009$ & $\$ 98,542$ & $\$ 2845$ \\
\hline AFW-AGG & Agriculture, Forestry and Waste & $-\$ 1352$ & $-\$ 32,039$ & 286,393 & $5,753,354$ & $\$ 22,539$ & $\$ 293,019$ & $-\$ 9117$ \\
\hline ALL-AGG & Total Aggregated Impact & $-\$ 127,273$ & $-\$ 1,270,749$ & $1,325,666$ & 25,973,101 & $\$ 95,554$ & $\$ 1,055,317$ & $-\$ 72,798$ \\
\hline
\end{tabular}


Annex 2: Energy Security Indicators (\% Change from Reference) and Environmental Indicators

\begin{tabular}{|c|c|c|c|c|c|c|c|c|c|c|}
\hline \multirow{2}{*}{\multicolumn{2}{|c|}{ Selected Policy Measures }} & \multicolumn{6}{|c|}{ Energy Security Indicators } & \multicolumn{3}{|c|}{ Environmental Indicators } \\
\hline & & \multirow{2}{*}{$\begin{array}{c}\begin{array}{c}\text { Change in } \\
\text { imported } \\
\text { oil }\end{array} \\
\begin{array}{c}2010-2030 \\
\text { levelized }\end{array} \\
\end{array}$} & \multirow{2}{*}{\begin{tabular}{|c|}
$\begin{array}{c}\text { Change ir } \\
\text { primary } \\
\text { energy } \\
\text { diversity }\end{array}$ \\
$2010-2030$ \\
levelized
\end{tabular}} & $\begin{array}{l}\text { Change in } \\
\text { electric } \\
\text { generation } \\
\text { diversity }\end{array}$ & \multicolumn{2}{|c|}{$\begin{array}{c}\text { Change in } \\
\text { grid } \\
\text { summer peak } \\
\text { demand }\end{array}$} & $\begin{array}{l}\text { Change in } \\
\text { energy } \\
\text { intensity }\end{array}$ & \multicolumn{2}{|c|}{$\begin{array}{c}\text { GHG } \\
\text { emissions } \\
\text { reductions } \\
\text { MMtCO2e }\end{array}$} & $\begin{array}{c}\text { Cost } \\
\text { effectiveness } \\
\$ / \text { tCO2e }\end{array}$ \\
\hline Sector & Policy Description & & & $\begin{array}{c}\text { 2010-2030 } \\
\text { levelized }\end{array}$ & $\begin{array}{l}\text { 2010-2030 } \\
\text { levelized }\end{array}$ & $\begin{array}{c}\text { 2010-2030 } \\
\text { levelized }\end{array}$ & 2020 & & 2010-2030 & $0 \quad 2010-2030$ \\
\hline EHS-1 & $\begin{array}{l}\text { National Renewable } \\
\text { Electricity Standard-20\% } \\
\text { by } 2030\end{array}$ & $0.2 \%$ & $0.5 \%$ & $6.0 \%$ & $-0.5 \%$ & $0.4 \%$ & & 0.03 & 2,559 & 49.08 \\
\hline EHS-2 & $\begin{array}{l}\text { Incentives for Combined } \\
\text { Heat and Power }\end{array}$ & $0.0 \%$ & $0.5 \%$ & $-0.1 \%$ & $0.0 \%$ & $0.0 \%$ & & 9.02 & 236 & -57.65 \\
\hline EHS-AGG & $\begin{array}{l}\text { Electricity and Heat } \\
\text { Supply }\end{array}$ & $0.2 \%$ & $1.0 \%$ & $6.1 \%$ & $-0.5 \%$ & $0.3 \%$ & & 4.26 & 2947 & 39.08 \\
\hline RCI-1 & $\begin{array}{l}\text { Industrial Process Efficiency } \\
\text { and DSM Measures }\end{array}$ & $-0.1 \%$ & $3.0 \%$ & $1.0 \%$ & $0.0 \%$ & $-1.3 \%$ & 127 & 7.09 & 2,773 & -29.96 \\
\hline RCI-2 & $\begin{array}{l}\text { DSM Programs for COM } \\
\text { \& RES Electricity \& } \\
\text { Natural gas Use }\end{array}$ & $0.8 \%$ & $3.6 \%$ & $8.1 \%$ & $-6.3 \%$ & $-1.8 \%$ & 160 & 0.28 & 4,869 & -19.16 \\
\hline RCI-3 & Zero Net Energy Buildings & $0.0 \%$ & $2.3 \%$ & $5.3 \%$ & $-3.6 \%$ & $-0.9 \%$ & & 3.65 & 2,329 & -68.61 \\
\hline RCI-4 & Appliance Standards & $0.0 \%$ & $0.8 \%$ & $2.4 \%$ & $-2.5 \%$ & $-0.3 \%$ & & 0.99 & 529 & -253.93 \\
\hline RCI-5 & $\begin{array}{l}\text { Advanced Building Codes-- } \\
\text { Commercial \& Residential }\end{array}$ & $0.0 \%$ & $3.1 \%$ & $7.0 \%$ & $-4.5 \%$ & $-1.4 \%$ & & 7.78 & 3,687 & -40.22 \\
\hline RCI-AGG & $\begin{array}{l}\text { Residential, Commercial, } \\
\text { Industrial }\end{array}$ & $0.0 \%$ & $5.6 \%$ & $9.6 \%$ & $-7.4 \%$ & $-3.5 \%$ & 298 & 8.13 & 9103 & -46.08 \\
\hline TLU-1 & Rebates for PHEVs and EVs & $-1.0 \%$ & $0.8 \%$ & $-0.4 \%$ & $0.0 \%$ & $-0.2 \%$ & & 8.06 & 351 & 222.02 \\
\hline TLU-2 & $\begin{array}{l}\text { National Renewable Fuel } \\
\text { Standard—Post } 2022\end{array}$ & $-1.5 \%$ & $0.0 \%$ & $0.1 \%$ & $0.0 \%$ & $0.1 \%$ & & 1.94 & 629 & 54.63 \\
\hline TLU-3 & $\begin{array}{l}\text { Smart Growth—Land Use } \\
\text { —-Strong }\end{array}$ & $-0.7 \%$ & $0.6 \%$ & $0.0 \%$ & $0.0 \%$ & $-0.2 \%$ & & 4.23 & 339 & -570.18 \\
\hline TLU-4 & Public Transit & $-0.3 \%$ & $0.2 \%$ & $-0.1 \%$ & $0.0 \%$ & $0.0 \%$ & & 5.60 & 109 & 264.54 \\
\hline TLU-5 & $\begin{array}{l}\text { Anti-Idling Technologies } \\
\text { and Practices-Rapid } \\
\text { response }\end{array}$ & $-0.5 \%$ & $0.5 \%$ & $0.0 \%$ & $0.0 \%$ & $-0.1 \%$ & & 2.24 & 235 & -98.53 \\
\hline TLU-6 & $\begin{array}{l}\text { Mode Shift from Truck to } \\
\text { Rail }\end{array}$ & $-2.2 \%$ & $1.5 \%$ & $0.0 \%$ & $0.0 \%$ & $-0.5 \%$ & & 3.00 & 953 & -252.55 \\
\hline TLU-7 & $\begin{array}{l}\text { National CAFE } \\
\text { Standard-Post } 2025 \text { targets }\end{array}$ & $-0.7 \%$ & $0.3 \%$ & $-0.4 \%$ & $0.0 \%$ & $-0.1 \%$ & & 3.06 & 184 & 447.17 \\
\hline TLU-AGG & $\begin{array}{l}\text { Transportation and Land } \\
\text { Use }\end{array}$ & $-4.9 \%$ & $2.7 \%$ & $-0.6 \%$ & $0.0 \%$ & $-1.0 \%$ & & 1.67 & 2077 & -80.93 \\
\hline AFW-1 & $\begin{array}{l}\text { Crop Production \& Nutrient } \\
\text { Management Practices }\end{array}$ & $0.0 \%$ & $0.0 \%$ & $0.0 \%$ & $0.0 \%$ & $0.0 \%$ & & 9.18 & 495 & 5.64 \\
\hline AFW-2 & $\begin{array}{l}\text { Agricultural Livestock Ma- } \\
\text { nure Management Practices }\end{array}$ & $0.0 \%$ & $0.0 \%$ & $0.0 \%$ & $0.0 \%$ & $0.0 \%$ & & 5.79 & 198 & 12.03 \\
\hline AFW-3 & Forest Retention Practices & $0.0 \%$ & $0.0 \%$ & $0.0 \%$ & $0.0 \%$ & $0.0 \%$ & & 4.00 & 100 & 4.62 \\
\hline AFW-4 & $\begin{array}{l}\text { Reforestation Management } \\
\text { Practices }\end{array}$ & $0.0 \%$ & $0.0 \%$ & $0.0 \%$ & $0.0 \%$ & $0.0 \%$ & & 4.41 & 371 & 3.96 \\
\hline AFW-5 & $\begin{array}{l}\text { Urban Forest Management } \\
\text { Practices }\end{array}$ & $0.0 \%$ & $0.3 \%$ & $1.1 \%$ & $-1.2 \%$ & $-0.1 \%$ & & 6.82 & 334 & 98.12 \\
\hline AFW-6 & $\begin{array}{l}\text { Integrated Waste Reduction, } \\
\text { Recycling and LGF } \\
\text { Utilization }\end{array}$ & $0.0 \%$ & $2.5 \%$ & $0.6 \%$ & $0.0 \%$ & $-1.0 \%$ & 106 & 6.69 & 2,622 & -28.28 \\
\hline AFW-AGG & $\begin{array}{l}\text { Agriculture, Forestry } \\
\text { and Waste }\end{array}$ & $0.0 \%$ & $2.6 \%$ & $1.8 \%$ & $-1.1 \%$ & $-1.1 \%$ & 156 & 6.57 & 4175 & -6.49 \\
\hline ALL-AGG & Total Aggregated Impact & $-5.0 \%$ & $6.8 \%$ & $9.3 \%$ & $-7.5 \%$ & $-4.8 \%$ & 465 & 5.66 & 13,448 & -44.61 \\
\hline
\end{tabular}

